\title{
Bevacizumab biosimilars: scientific justification for extrapolation of indications
}

\author{
Barbara Melosky*,1, David A Reardon², Andrew B Nixon³, Janakiraman Subramanian ${ }^{4}$, \\ Angel H Bair ${ }^{5}$ \& Ira Jacobs 5 \\ ${ }^{1}$ Medical Oncology, British Columbia Cancer Agency, University of British Columbia, Vancouver, BC V5Z 4E6, Canada \\ ${ }^{2}$ Center for Neuro-Oncology, Dana-Farber Cancer Institute, Boston, MA 02215, USA \\ ${ }^{3}$ Department of Medicine/Medical Oncology, Duke University School of Medicine, Durham, NC 27710, USA \\ ${ }^{4}$ Division of Oncology, Saint Luke's Cancer Institute, Kansas City, MO 64111, USA \\ ${ }^{5}$ Pfizer Inc., New York, NY 10017, USA \\ *Author for correspondence: BMelosky@bccancer.bc.ca
}

The first biosimilar of bevacizumab was approved by the US FDA; other potential biosimilars of bevacizumab are in late-stage clinical development. Their availability offers opportunity for increased patient access across a number of oncologic indications. The regulatory pathway for biosimilar approval relies on the totality of evidence that includes a comprehensive analytical assessment, and a clinical comparability study in a relevant disease patient population. Extrapolation of indications for a biosimilar to other eligible indications held by the originator, in the absence of direct clinical comparison, frequently forms part of the regulatory judgment. Herein, we consider the evidence required to demonstrate biosimilarity for bevacizumab biosimilars, with particular focus on the rationale for extrapolation across oncologic indications.

First draft submitted: 19 January 2018; Accepted for publication: 26 March 2018; Published online: 25 April 2018

Keywords: ABP $215 \bullet$ bevacizumab • biosimilar • extrapolation • metastatic colorectal cancer $\bullet$ non-small-cell lung cancer $\bullet$ PF-06439535 • totality of evidence

Bevacizumab (Avastin ${ }^{\circledR}$; Roche, Welwyn Garden City, UK; Genentech, CA, USA) is a monoclonal antibody directed against VEGF. It is approved in Europe and the USA for the treatment of a range of cancers, including metastatic or recurrent nonsquamous non-small-cell lung cancer (NSCLC), metastatic renal cell carcinoma, metastatic colorectal cancer (CRC), cervical cancer, and platinum-resistant or platinum-sensitive recurrent epithelial ovarian, fallopian tube and primary peritoneal cancers [1,2]. In addition, in the USA, Japan, and many other countries, bevacizumab is indicated for the treatment of patients with glioblastoma. In Europe, it is also authorized for use in metastatic breast cancer and in combination with erlotinib for the first-line treatment of advanced, metastatic nonsquamous NSCLC with EGF receptor-activating mutations [3]. Randomized Phase III trials have shown that progression-free survival (PFS) and/or overall survival (OS) in patients with these cancers is prolonged with treatment combining bevacizumab with standard chemotherapy (Table 1) [4-12]. Nonetheless, patient access to bevacizumab may be limited.

Barriers to bevacizumab use stem from factors such as insurance coverage and cost of treatment, manufacturing and supply and uncertainty as to its cost-effectiveness in some clinical settings [13-15]. A survey conducted by the European Society of Medical Oncology Consortium found budget constraints, affordability and issues related to the manufacture and assured supply of the product were cited most frequently as reasons for access to bevacizumab to be considered suboptimal [13]. Oncologists who were surveyed in the USA, Europe and in some emerging market countries (Brazil, Mexico and Turkey) stated the major barriers to prescribing bevacizumab were the high out-of-pocket costs for patients and a lack of reimbursement. These barriers were commonly cited as reasons for reducing the number of drug treatment cycles that were planned for patients [15].

Protein-based biologics, such as bevacizumab, are produced in living cells rather than by chemical synthesis, and are large and structurally complex [16]. Their structure and activity are influenced by events that occur during biosynthesis, including post-translational modifications, such as the covalent addition of functionality (including

Future $\because \%$ Medicine 
Table 1. Key clinical studies supporting approved indications for bevacizumab.

\begin{tabular}{|c|c|c|c|c|}
\hline Patient population & Treatments & Efficacy (primary end point) & Safety & Ref. \\
\hline $\begin{array}{l}\text { Previously untreated } \\
\text { metastatic CRC }\end{array}$ & IFL plus (BEV or PBO) & $\begin{array}{l}\text { Median survival: } 20.3 \text { and } 15.6 \text { months in } \\
\text { the IFL + BEV and IFL + PBO groups, } \\
\text { respectively (HR for death: } 0.66 \text { [p }<0.001] \text { ) }\end{array}$ & $\begin{array}{l}\text { Grade } 3 \text { hypertension: } 11.0 \text { and } 2.3 \% \text { in the } \\
\text { IFL + BEV treatment and IFL + PBO arm, } \\
\text { respectively }\end{array}$ & 4] \\
\hline $\begin{array}{l}\text { Recurrent or advanced } \\
\text { NSCLC (stage IIIB or IV) }\end{array}$ & $\begin{array}{l}\text { PTX and carboplatin with } \\
\text { or without BEV }\end{array}$ & $\begin{array}{l}\text { Median survival: } 12.3 \text { and } 10.3 \text { months in } \\
\text { the chemotherapy + BEV group and } \\
\text { chemotherapy alone group, respectively } \\
\text { (HR for death: } 0.79[p=0.003] \text { ) }\end{array}$ & $\begin{array}{l}\text { Clinically significant bleeding: } 4.4 \text { and } 0.7 \% \text { for } \\
\text { the chemotherapy }+B E V \text { and chemotherapy } \\
\text { alone groups, respectively }(p<0.001) \\
\text { Fifteen treatment-related deaths in the } \\
\text { chemotherapy }+ \text { BEV group, including five from } \\
\text { pulmonary hemorrhage }\end{array}$ & 5] \\
\hline $\begin{array}{l}\text { Previously untreated } \\
\text { metastatic RCC }\end{array}$ & $\mathrm{IFN}+(\mathrm{BEV}$ or $\mathrm{PBO})$ & $\begin{array}{l}\text { Median PFS: } 10.2 \text { and } 5.4 \text { months in the } \\
\text { BEV + IFN group and PBO + IFN control } \\
\text { group, respectively (HR: } 0.63[95 \% \mathrm{Cl}: \\
0.52-0.75] ; \mathrm{p}=0.0001)\end{array}$ & $\begin{array}{l}\text { (Grade } \geq 3 \text { AEs) fatigue: } 12 \text { and } 8 \% \text {; asthenia } \\
10 \text { and } 7 \% \text {; in the BEV }+ \text { IFN and PBO + IFN } \\
\text { control group, respectively } \\
\text { Deaths due to AEs: eight }(2 \%) \text { patients who } \\
\text { received } \geq 1 \text { doses of BEV; seven ( } 2 \% \text { ) of those } \\
\text { who did not receive BEV }\end{array}$ & 6] \\
\hline $\begin{array}{l}\text { Initial treatment for } \\
\text { metastatic breast cancer }\end{array}$ & PTX alone or with BEV & $\begin{array}{l}\text { Median PFS: } 11.8 \text { and } 5.9 \text { months for } \\
\text { PTX }+ \text { BEV and PTX alone, respectively (HR: } \\
0.60 ; p<0.001)\end{array}$ & $\begin{array}{l}\text { Grade } 3 / 4 \text { hypertension: } 14.8 \text { and } 0.0 \% \\
(p<0.001) ; \text { proteinuria: } 3.6 \text { and } 0.0 \%(p<0.001) \text {; } \\
\text { headache: } 2.2 \text { and } 0.0 \%(p=0.008) ; \\
\text { cerebrovascular ischemia: } 1.9 \text { and } 0.0 \%(p=0.02) ; \\
\text { infection: } 9.3 \text { and } 2.9 \%(p<0.001) \text { in the } \\
\text { PTX + BEV and PTX alone groups, respectively } \\
\text { Overall, febrile neutropenia was }<1 \%\end{array}$ & [7] \\
\hline Recurrent glioblastoma & $\begin{array}{l}\text { BEV alone or in } \\
\text { combination with } \\
\text { irinotecan }\end{array}$ & $\begin{array}{l}\text { Estimated } 6 \text {-month PFS rates: } 50.3 \text { and } \\
42.6 \% \text { in the BEV + irinotecan and BEV } \\
\text { alone groups, respectively. ORR was } 37.8 \\
\text { and } 28.2 \% \text {, respectively }\end{array}$ & $\begin{array}{l}\text { Most common grade } \geq 3 \text { AEs were convulsion } \\
(13.9 \%) \text {, neutropenia }(8.9 \%) \text { and fatigue }(8.9 \%) \text { in } \\
\text { the BEV + irinotecan group ( } 65.8 \% \text { of patients); } \\
\text { hypertension }(8.3 \%) \text { and convulsion }(6.0 \%) \text { in the } \\
\text { BEV alone group ( } 46.4 \% \text { of patients) }\end{array}$ & [8] \\
\hline $\begin{array}{l}\text { Recurrent, persistent or } \\
\text { metastatic cervical cancer }\end{array}$ & $\begin{array}{l}\text { Chemotherapy } \\
\text { (cisplatin + PTX) or } \\
\text { (topotecan + PTX) each } \\
\text { with or without BEV }\end{array}$ & $\begin{array}{l}\text { Overall survival: } 17.0 \text { and } 13.3 \text { months for } \\
\text { the BEV + chemotherapy and } \\
\text { chemotherapy alone groups, respectively } \\
\text { (HR for death: } 0.71 \text { [98\% Cl: } 0.54-0.95] ; \\
p=0.004 \text { ) }\end{array}$ & $\begin{array}{l}\text { Hypertension of grade } \geq 2: 25 \text { and } 2 \% \text {; } \\
\text { thromboembolic events of grade } \geq 3: 8 \text { and } 1 \% \text {; } \\
\text { GI fistulas of grade } \geq 3: 3 \text { and } 0 \%: \text { in the } \\
\text { BEV }+ \text { chemotherapy and chemotherapy alone } \\
\text { groups, respectively }\end{array}$ & 9] \\
\hline $\begin{array}{l}\text { Platinum-resistant ovarian } \\
\text { cancer }\end{array}$ & $\begin{array}{l}\text { Single-agent } \\
\text { chemotherapy (PEGylated } \\
\text { liposomal doxorubicin, } \\
\text { PTX or topotecan) alone } \\
\text { or with BEV }\end{array}$ & $\begin{array}{l}\text { Median PFS: } 6.7 \text { and } 3.4 \text { months with } \\
\text { chemotherapy in combination with BEV } \\
\text { and single-agent chemotherapy alone, } \\
\text { respectively (HR: } 0.48 \text { [ } 95 \% \text { Cl: } 0.38-0.60] \\
p<0.001 \text { ) }\end{array}$ & $\begin{array}{l}\text { Grade } \geq 2 \text { hypertension and proteinuria were } \\
\text { more common in patients receiving a } \\
\text { BEV-containing regimen } \\
\text { Gl perforation occurred in } 2.2 \% \text { of BEV-treated } \\
\text { patients }\end{array}$ & 10] \\
\hline $\begin{array}{l}\text { Previously untreated, } \\
\text { incompletely resectable } \\
\text { stage III or any stage IV } \\
\text { epithelial ovarian, primary } \\
\text { peritoneal or fallopian } \\
\text { tube cancer }\end{array}$ & $\begin{array}{l}\text { PTX }+ \text { carboplatin for } \\
\text { cycles } 1 \text { through } 6 \text { with } \\
\text { either PBO (cycles 2-22), } \\
\text { BEV (cycles 2-6) and PBO } \\
\text { (cycles 7-22) or BEV (cycles } \\
\text { 2-22) }\end{array}$ & $\begin{array}{l}\text { Median PFS: } 14.1,11.2 \text { and } 10.3 \text { months in } \\
\text { the BEV-throughout, BEV-initiation and } \\
\text { control group, respectively (HR relative to } \\
\text { control group for progression or death: } \\
0.717 \text { [95\% Cl: } 0.625-0.824] ; \mathrm{p}<0.001 \text { with } \\
\text { BEV-throughout; } 0.908 \text { [ } 95 \% \mathrm{Cl} \text { : } \\
0.795-1.040] ; \mathrm{p}=0.16 \text { with BEV-initiation) }\end{array}$ & $\begin{array}{l}\text { Hypertension requiring medical therapy: } 22.9 \text {, } \\
16.5 \text { and } 7.2 \% \text {; GI-wall disruption requiring } \\
\text { medical intervention: } 2.6,2.8 \text { and } 1.2 \% \text { in the } \\
\text { BEV-throughout, BEV-initiation and control } \\
\text { group, respectively }\end{array}$ & 1] \\
\hline $\begin{array}{l}\text { Platinum-sensitive } \\
\text { recurrent epithelial } \\
\text { ovarian, fallopian tube or } \\
\text { primary peritoneal cancer }\end{array}$ & GC with (PBO or BEV) & $\begin{array}{l}\text { Median PFS: } 12.4 \text { and } 8.4 \text { months for the } \\
\text { GC + BEV arm and GC + PBO arm, } \\
\text { respectively }(\mathrm{HR}: 0.484 ;[95 \% \mathrm{Cl}: \\
0.388-0.605] ; \mathrm{p}<0.0001)\end{array}$ & $\begin{array}{l}\text { Grade } \geq 3 \text { hypertension: } 17.4 \text { and }<1 \% \text {; } \\
\text { proteinuria: } 8.5 \text { and }<1 \% \text {; in the } \mathrm{GC}+\mathrm{BEV} \text { and } \\
\mathrm{GC}+\mathrm{PBO} \text { arm, respectively } \\
\text { Rates of neutropenia and febrile neutropenia } \\
\text { were similar between groups }\end{array}$ & 2] \\
\hline
\end{tabular}

5-FU: Fluorouracil; AE: Adverse events; BEV: Bevacizumab; CRC: Colorectal cancer; GC: Gemcitabine and carboplatin; GI: Gastrointestinal; HR: Hazard ratio; IFL: Irinotecan, 5-FU and leucovorin; IFN: Interferon- $\alpha 2 a ;$ NSCLC: Non-small-cell lung cancer; ORR: Objective response rates; PBO: Placebo; PFS: Progression-free survival; PTX: Paclitaxel; RCC: Renal cell carcinoma.

glycosylation, lipidation, hydroxylation, phosphorylation) and proteolytic cleavage of regulatory subunits or selective degradation, as well as during purification, formulation or storage [17]. Therefore, due to the complexity in terms of their structure and the methods used in their manufacture, some level of heterogeneity exists between batches of the same biologic product [18]. Although it is not possible to generate an exact copy of a biologic, a 'biosimilar' can be produced [19]. A biosimilar is similar in terms of its safety, purity and potency to an originator or reference biologic product that has already been licensed [19-21]. Biosimilars of originator biologic medicines, such as bevacizumab, offer the possibility of increasing patient access to treatments, from which improved clinical outcomes across healthcare systems may follow.

The patents on originator bevacizumab in Europe and the USA are near to expiry. The first bevacizumab biosimilar, ABP 215 (Mvasi ${ }^{\circledR}$; Amgen, CA, USA) has been approved by the US FDA for all eligible indications 
(i.e., not covered by regulatory exclusivity) authorized for the originator product [22]; other potential bevacizumab biosimilars are currently in development [23].

Many biologics, including bevacizumab, have multiple indications. Regulatory agencies permit extrapolation of data for a biosimilar, allowing approval for its use in an eligible indication for which the originator is authorized without the need for a comparative clinical trial. However, adequate scientific justification and the totality of evidence' demonstrating biosimilarity are required to support approval of extrapolation [19,21,24].

This review provides an overview of bevacizumab and its mechanism of action across indications, and examines the totality of evidence approach used to support the approval of biosimilars, as well as the science underlying the concept of extrapolation.

\section{VEGF \& bevacizumab mechanism of action}

VEGF plays a central role in tumor angiogenesis and has been implicated in both tumor vascularization and metastases $[25,26]$. In addition to the angiogenic process, the VEGF/VEGF receptor (VEGFR) pathway may be involved in a direct tumor-promoting pathway [27] and VEGF inhibition may have direct cytotoxic effects [28]. VEGF expression is associated with poorer prognosis or more aggressive disease in NSCLC [29], CRC [30], glioblastoma [31] and ovarian cancer [32]. In NSCLC, VEGF expression is associated with metastatic nodal involvement, decreased OS and PFS and increased tumor neovascularization [33]. In CRC, VEGF is significantly elevated in patients with liver metastases compared with healthy controls and patients without liver metastases, as well as in patients with node-positive CRC compared with those with node-negative CRC [34]. VEGF is often overexpressed in ovarian cancer, which is associated with an increased risk of metastatic disease and poor prognosis [35,36].

Bevacizumab binds a continuous epitope in VEGF in vitro and prevents binding of VEGF with VEGFR on the surface of endothelial cells [37], thereby preventing ligand-receptor interaction and downstream signaling [38]. Bevacizumab acts via inhibition of VEGF signaling and may exert its antitumor effects through inhibition of new vessel growth, regression of newly formed vessels, normalization of the vasculature to facilitate the delivery of cytotoxic chemotherapy and direct effects on tumor cells [39,40]. In vitro, bevacizumab inhibits VEGF-induced effects, including cell growth, increased permeability, nitric oxide production and cell migration $[41,42]$. Indirect clinical evidence from patients supports the hypothesis that bevacizumab has primarily cytostatic effects, indicating it inhibits the growth of new blood vessels [40].

Pharmacodynamic (PD) biomarkers, such as circulating VEGF and PGF (a VEGF family member), demonstrate a consistent effect in different tumor types after bevacizumab administration, in that circulating levels increase in response to anti-VEGF treatment of patients with various malignancies [43]. Overall, data support a consistent mechanism of action for bevacizumab, targeting VEGF and angiogenesis across various tumor types.

\section{Demonstrating biosimilarity}

In contrast with the development of a new biologic medicine, the goal of biosimilar drug development is not to establish efficacy and safety in one or more disease indications, since these are already established for the originator. Instead, the goal is to establish similarity of the biosimilar to the originator in terms of quality, safety and efficacy, thereby providing assurance there should be no meaningful clinical difference between them $[44,45]$. Because of the complexities and proprietary nature of the manufacturing conditions for biologics, it is not possible for the originator to be duplicated exactly and some level of heterogeneity will exist between the biosimilar and the originator [46]. Thus, regulatory agencies such as the EMA and FDA, as well as the WHO, have issued specific guidelines for the development and approval of biosimilars [19-21]. Although minor differences exist between the guidelines, demonstrating structural, functional and clinical similarity to the originator product is a requirement in all cases [19-21]. Regulatory authorities have not provided a definitive battery of analyses that need to be conducted, and each potential biosimilar is developed and approved on an individual basis. Biosimilar approval is granted on evaluation of the totality of evidence, encompassing the comparative analytical, nonclinical, pharmacokinetic $(\mathrm{PK}) / \mathrm{PD}$ and clinical data $[46,47]$. Thus, the development pathway and requirements for approval for biosimilars differ from those of new biologic medicines, and from those for generic versions of chemically synthesized smallmolecule drugs (Figure 1).

Biosimilarity is established through a rigorous, stepwise comparison of the proposed biosimilar and the reference product [19-21]. The foundation of biosimilarity rests on the demonstration of similarity in structure and function. Analytical assessments are performed that compare the originator product and potential biosimilar, to confirm similarity in primary sequence, higher-order protein structure, post-translational modifications, biochemical quality 


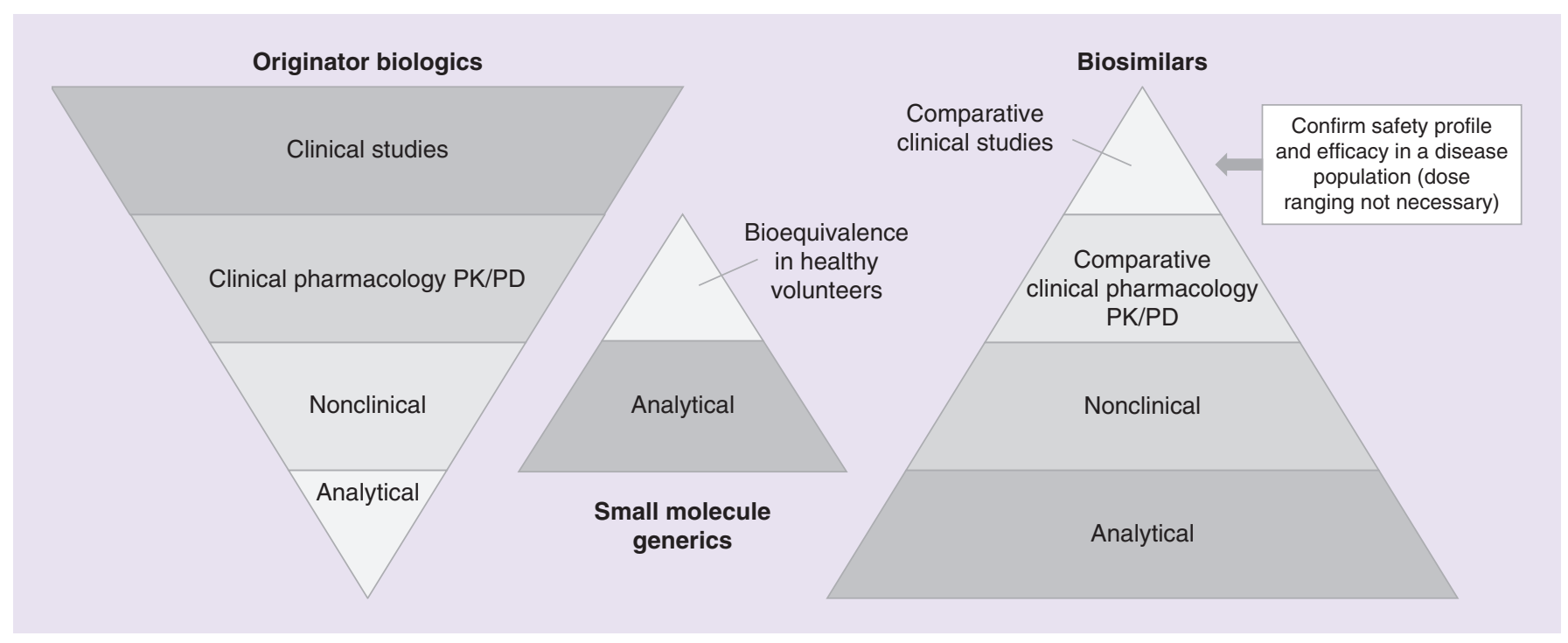

Figure 1. Development pathways for originator biologics, biosimilars and generic versions of small-molecule drugs.

PK/PD: Pharmacokinetic/pharmacodynamic.

Adapted with permission from Future Medicine Ltd $\left.^{(}\right)$(2017) [48].

attributes and biologic activity [49-51]. The sensitivity of in vitro assays provides the greatest likelihood of detecting minor differences between the proposed biosimilar and the originator product. Structural assessments are required to establish that the proposed biosimilar and originator share the same amino acid composition and primary sequence [52]. In addition, results of analytical tests should show high similarity between the products in terms of post-translational modifications, product isoforms, product purity, higher-order structure and protein-folding. Functional activity characterization is conducted to confirm the proposed biosimilar has a similar mechanism of action to the originator product, as well as to resolve any remaining uncertainty arising from the structural analyses as to whether any minor differences identified are likely to have clinically meaningful effects [20,21]. Since biologics typically depend on specific binding to the target antigen and potential follow-on effector function(s) to achieve their clinical effects [53], demonstrating similarity in functional activity of the proposed biosimilar and the originator product also serves as the basis for extrapolation. For monoclonal antibodies, functional assessments typically include those that evaluate antigen binding (Fab biologic function) and Fc effector biologic functions, including antibody-dependent cellular cytotoxicity and complement-dependent cytotoxicity activity [54]. Although the primary sequence and higher-order structure of the Fc region of bevacizumab are important for VEGF binding, this does not induce complement-dependent cytotoxicity or antibody-dependent cellular cytotoxicity activity [42]. This finding is consistent with a mechanism of antitumor activity via neutralization of secreted VEGF activity involving the Fab region of bevacizumab, and it is essential that this aspect is reflected in the analytical similarity plan for a proposed biosimilar. Comparative assessment of the functional activity of a proposed biosimilar and the originator should be capable of establishing that any differences in quality attributes are unlikely to be clinically relevant, as well as to provide a rationale for the approach to in vivo and clinical evaluation [21,55]. Regulatory agencies appear to be moving away from requiring nonclinical in vivo evaluations. This development is because the extensive in vitro analytical characterization establishes the core aspects of biosimilarity, and it is therefore unlikely that in vivo nonclinical studies would identify new safety signals [56,57]. Consequently, biosimilar developers and regulatory authorities are in discussions surrounding the relevance of in vivo nonclinical studies [56].

The goal of comparative clinical studies is to demonstrate that clinically meaningful differences between the originator product and proposed biosimilar do not exist, in terms of in PK/PD, therapeutic effect or safety, including immunogenicity [19-21]. Demonstration of PK similarity in a head-to-head study, typically in healthy subjects, is an essential requirement to support biosimilarity, and is the first step of a biosimilar clinical program [1921]. Once PK similarity has been demonstrated, generating the data to directly compare the efficacy, safety and immunogenicity of the potential biosimilar to the originator in patients in a clinical study (or studies) is the final step in establishing biosimilarity. A product can only be approved as a biosimilar by following rigorous assessment 
of the totality of evidence, comprising analytical structural and nonclinical functional assessments, clinical PK and efficacy data [19-21].

\section{Principles of extrapolation}

Extrapolation of data is a well-established principle that is based on applying the conclusions from a study conducted in one population to make inferences for another population, and is widely accepted by regulatory bodies. Extrapolation is intended to avoid clinical trials conducted unnecessarily, and to help ensure the most efficient allocation of clinical research resources.

Extrapolation of indications for biosimilars is governed by specific guidelines [20,21] and figures highly in the deliberations of regulatory authorities, since it often forms part of licensing applications for biosimilars. However, extrapolation of data is not unusual and regulatory bodies have shown they are comfortable in applying this principle by doing so between one originator biologic and another. For instance, the initial approval of the monoclonal antibody trastuzumab (Herceptin ${ }^{\circledR}$; Roche) was for use of an intravenously administered formulation for infusion, which is now indicated for the treatment of patients with early and metastatic HER2-positive breast cancer and in metastatic gastric cancer [58]. However, a fixed-dose formulation for subcutaneous administration was subsequently developed [59]. In an open-label, two-part, Phase I/Ib study in healthy male subjects and female patients with HER2-positive early breast cancer, a subcutaneous trastuzumab dose of $8 \mathrm{mg} / \mathrm{kg}$ was found to result in exposure comparable to an intravenous trastuzumab dose of $6 \mathrm{mg} / \mathrm{kg}$ [60]. A single pivotal study, using pathological complete response $(\mathrm{pCR})$ as the coprimary efficacy end point, demonstrated that a fixed-dose trastuzumab subcutaneous formulation was noninferior, since the lower limit of the $95 \%$ CI (-4.0-13.4) for the difference in pCR between groups $(4.7 \%)$ was greater than the prespecified margin of $-12.5 \%$, and had a similar safety profile to the established intravenous formulation, in patients with nonmetastatic, HER2-positive, locally advanced or inflammatory breast cancer treated with neoadjuvant chemotherapy [61,62]. Noninferiority between treatments in the PK coprimary end point was also demonstrated in that the geometric mean ratio of the trough concentration $\left(\mathrm{C}_{\text {trough }}\right)$ at predose cycle 8 before surgery was 1.33 ( $90 \%$ CI: $1.24-1.44$ ), with the lower limit of the two-sided $90 \%$ CI greater than the prespecified noninferiority margin of 0.8 [61]. Extrapolation of the efficacy data to the metastatic breast cancer setting was considered acceptable [63].

Extrapolation, as it applies to biosimilars, is the scientific rationale that bridges all the data collected from one indication of the biosimilar to other eligible approved indications of the originator [24]. Importantly, extrapolation reduces or eliminates the need for repeating indication-specific clinical studies that have established the safety and efficacy for the originator product $[19-21,24,45]$. The extent of data required for the scientific justification of extrapolation may vary somewhat among regulatory authorities [64]. Nonetheless, consideration of extrapolation by the EMA and FDA requires that demonstration of biosimilarity with the originator must be shown across a comprehensive comparability exercise, encompassing the evaluation of efficacy, safety and immunogenicity in an indication involving a clinically relevant mechanism of action and receptors [19-21]. The overriding consideration in the selection of the patient population's disease is that it should be sufficiently sensitive to identify a difference with respect to the potential biosimilar versus the originator, should one exist [19-21].

The FDA guidance stipulates that the scientific justification for extrapolation should address the following key aspects, which bevacizumab satisfies. First, the mechanism of action in each condition should be understood, as evidenced by: target/receptors, receptor binding, dose/concentration response, pattern of molecular signaling upon engagement of the target/receptors, relationships between product structure and target/receptor interactions, and location and expression of target/receptors [21,65]. Overall, bevacizumab has a consistent mechanism of action across indications, targeting VEGF and angiogenesis in various tumor types.

Also, the PK and biodistribution of the originator product in the condition where the proposed biosimilar was tested and in the extrapolated indication should be understood. Similarly, the immunogenicity and expected toxicities in each condition of use and patient population should be known [21]. A population PK analysis was conducted on data from eight clinical trials of bevacizumab in patients $(n=491)$ with solid tumors, with treatment dose ranging from 1 to $20 \mathrm{mg} / \mathrm{kg}$ [66]. The majority (79\%) of patients received bevacizumab in combination with various chemotherapy regimens. Bodyweight and gender were the most significant covariates to explain interpatient variability for both clearance and central compartment volume of distribution. The effect of chemotherapy on bevacizumab clearance was minimal. Since more than $98 \%$ of the circulating VEGF is predicted to be bound with bevacizumab at the clinical dose rates in CRC $(2.5 \mathrm{mg} / \mathrm{kg}$ per week) and in breast cancer and NCSLC 
( $5 \mathrm{mg} / \mathrm{kg}$ per week), covariate effects were considered unlikely to significantly influence efficacy. The PK properties of bevacizumab are acknowledged as being consistent across the approved indications [65].

\section{Bevacizumab biosimilars: considerations for development \& approval}

Data from the comprehensive functional assessments that were performed for ABP 215 were described in the briefing document submitted as part of the Biologics License Application [65], and illustrate the type of studies used to assess similarity of a bevacizumab biosimilar with the originator. Functional similarity to originator bevacizumab was examined in multiple preclinical pharmacologic assessments [67]. Because bevacizumab targets VEGF, assessment of the biologic activity included comparative binding studies to VEGF and VEGF isoforms by surface plasmon resonance and to cell-surface expressed neonatal $F_{c}$ receptor and to Fc gamma receptor-IIIa by chemiluminescent immunoasssay. A human umbilical vein endothelial cell-based assay was used to compare the inhibitory effects on proliferation and VEGFR2 phosphorylation. Antitumor activity in terms of inhibition of both tumor growth and tumor-associated vasculature was compared in two tumor xenograft models [67]. Across multiple functional assessments, ABP 215 was similar to bevacizumab [65]. The PK similarity of ABP 215 to both bevacizumab from the USA (bevacizumab-US) and bevacizumab from the EU (bevacizumab-EU) and of bevacizumab-US to bevacizumab-EU was demonstrated in a randomized, single-blind, single-dose study in healthy male subjects [68]. In a Phase III study in patients with nonsquamous NSCLC, the primary end point was met since the two-sided $90 \% \mathrm{CI}$ of the risk ratio of the objective response rate (ORR; 0.93 [90\% CI: 0.80-1.09]) was within the prespecified margin (0.67-1.50), supporting clinical equivalence of bevacizumab and ABP 215 [69]. Safety aspects and immunogenicity were also comparable to bevacizumab.

Additional insight into the assessment of a potential bevacizumab biosimilar is found in the studies that evaluated the structural and functional similarity of PF-06439535 to bevacizumab-EU and bevacizumab-US [70]. Peptide mapping demonstrated the amino acid sequence of PF-06439535 was identical to that of bevacizumab-EU and bevacizumab-US. N-linked oligosaccharide profiling identified similar levels of $\mathrm{N}$-linked oligosaccharides in the products. Imaged capillary electrophoresis demonstrated that predominant charge isoforms were similar. Biologic activity, measured via inhibition of VEGF-induced cell proliferation in human umbilical vein endothelial cells and binding to the four major VEGF isoforms, was similar [70]. In addition, comparative in vivo nonclinical animal studies have evaluated the potential biosimilar bevacizumab in terms of toxicokinetics and potential toxicity [70].

The PK similarity of PF-06439535, bevacizumab-EU and bevacizumab-US, and between bevacizumab-EU and bevacizumab-US, following a single intravenous dose were compared in 102 healthy male subjects [71]. The three study drugs exhibited similar PK profiles, as the $90 \%$ CIs for the ratios of maximum serum concentration, area under the serum concertation-time curve from time zero to time of last quantifiable concentration and zero to infinity were all within $80.00-125.00 \%$ bioequivalence acceptance window for the comparisons of PF06439535 to bevacizumab-EU or bevacizumab-US, and of bevacizumab-EU to bevacizumab-US. The numbers of subjects testing positive for antidrug antibodies were similarly low across treatment arms; none tested positive for neutralizing antibodies. The reporting of treatment-related adverse events in the PF-06439535 (15.2\% of subjects), bevacizumab-EU (25.7\%) and bevacizumab-US (18.2\%) arms indicated comparable safety profiles between treatments [71].

It is essential that comparative clinical studies are conducted in an appropriate population and with a clinical end point capable of detecting potential differences between treatments. In particular, the potential for variability in outcomes due to disease- or patient-related factors should be minimized, so any observed differences can be ascribed to the drug itself and not the patient population [72]. Biosimilar manufacturers usually engage with regulators to select the most appropriate study population, which is based on evaluation of historical studies of the originator product, practical considerations and input from clinicians in order to address advances in clinical practice and reflect the latest knowledge of the disease [20,21]. The impact of comedication or previous therapy should be understood, with limited potential for having a confounding influence on outcomes. In particular, when considering the most sensitive population in which to conduct comparative studies in oncology, the indication where the originator is approved for first-line treatment may be for use with or without concomitant chemotherapy. Another consideration in the design of a comparative clinical study is selection of a suitable end point [73-75]. End points should be appropriate to the disease state and sensitive enough to detect clinically relevant differences in efficacy and safety, if any exist, between the potential biosimilar and the originator. A clinical end point measuring activity (such as ORR) may be preferred by regulatory authorities to a survival-based end point (typically used when evaluating novel biologics for oncology indications) for clinical comparisons of a potential biosimilar [75]; 


\begin{tabular}{|c|c|c|c|c|c|c|c|c|}
\hline \multirow{2}{*}{$\begin{array}{l}\text { Product } \\
\text { (manufacturer) }\end{array}$} & \multirow{2}{*}{$\begin{array}{l}\text { Trial registration } \\
\text { ID }\end{array}$} & \multirow{2}{*}{ Design } & \multirow[t]{2}{*}{ n } & \multicolumn{2}{|c|}{ Primary end point } & \multirow[t]{2}{*}{ Status } & \multirow[t]{2}{*}{ Completion } & \multirow[t]{2}{*}{ Outcome } \\
\hline & & & & Measure & Time frame & & & \\
\hline $\begin{array}{l}\text { ABP } 215 \\
\text { (Mvasi) } \\
\text { (Amgen) }\end{array}$ & NCT01966003 & $\begin{array}{l}\text { Randomized, DB } \\
\text { parallel group }\end{array}$ & 642 & ORR & $\leq 19$ weeks & Completed & $\begin{array}{l}\text { July } 2015 \\
\text { (primary) }^{\S}\end{array}$ & $\begin{array}{l}\text { Similar efficacy, } \\
\text { safety and IG } \\
\text { between ABP } 215 \\
\text { and BEV }[69,81]\end{array}$ \\
\hline $\begin{array}{l}\text { BCD-021 } \\
\text { (Biocad) }\end{array}$ & NCT01763645 & $\begin{array}{l}\text { Randomized, DB } \\
\text { parallel group }\end{array}$ & 138 & ORR & day 127 & $\begin{array}{l}\text { Active, not } \\
\text { recruiting }\end{array}$ & $\begin{array}{l}\text { December } 2014 \\
\text { (primary) }^{\S}\end{array}$ & $\begin{array}{l}\text { Similar efficacy, } \\
\text { safety and IG } \\
\text { between BCD-021 } \\
\text { and BEV [82] }\end{array}$ \\
\hline $\begin{array}{l}\text { BI } 695502 \\
\text { (Boehringer } \\
\text { Ingelheim) }\end{array}$ & NCT02272413 & $\begin{array}{l}\text { Randomized, DB } \\
\text { parallel group }\end{array}$ & 671 & ORR & $\leq 18$ weeks & $\begin{array}{l}\text { Ongoing, not } \\
\text { recruiting }\end{array}$ & $\begin{array}{l}\text { June } 2017 \\
\text { (primary) }^{\S}\end{array}$ & - \\
\hline $\begin{array}{l}\text { FKB238 (Centus } \\
\text { Biotherapeutics) }\end{array}$ & NCT02810457 & $\begin{array}{l}\text { Randomized, } \\
\text { DB, parallel } \\
\text { group }\end{array}$ & est. 730 & ORR & $\leq 12$ months & Recruiting & June 2019 (est.)§ & - \\
\hline $\begin{array}{l}\text { PF-06439535 } \\
\text { (Pfizer) }\end{array}$ & NCT02364999 & $\begin{array}{l}\text { Randomized, DB } \\
\text { parallel group }\end{array}$ & 719 & ORR & $\leq 19$ weeks & $\begin{array}{l}\text { Ongoing, not } \\
\text { recruiting }\end{array}$ & $\begin{array}{l}\text { May } 2017 \\
\left(\text { primary) }{ }^{\S}[80]\right.\end{array}$ & - \\
\hline $\begin{array}{l}\text { SB8 (Samsung } \\
\text { Bioepis) }\end{array}$ & NCT02754882 & $\begin{array}{l}\text { Randomized, DB } \\
\text { parallel group }\end{array}$ & est. 678 & ORR & $\leq 24$ weeks & $\begin{array}{l}\text { Active, not } \\
\text { recruiting }\end{array}$ & June 2018(est.) ${ }^{\S}$ & - \\
\hline \multicolumn{9}{|c|}{$\begin{array}{l}\text { †Only those potential biosimilars with trials in patients with nonsquamous non-small-cell lung cancer that are registered at ClinicalTrials.gov are included here; other potential biosimilars } \\
\text { may be in development. } \\
\ddagger \text { Approved by the US FDA ( } 14 \text { September 2017) [22]. } \\
\text { § Primary completion date refers to the final data collection for the primary outcome measure. Table last updated in December } 2017 \text {. }\end{array}$} \\
\hline
\end{tabular}

particularly, since the latter end point can be influenced by factors other than product-related differences between products [20]. Use of a survival-based end point may require a larger patient population and with longer follow-up, and may not be amenable to assess the impact of switching. For instance, equivalence of ORR was chosen as the primary end point in a pivotal comparative efficacy and safety study of the rituximab biosimilar GP2013 (Rixathon ${ }^{\circledR}$; Sandoz, Kundl, Austria) and rituximab in patients $(\mathrm{n}=627)$ with previously untreated advanced follicular lymphoma [76]. Similarity was demonstrated as the entire 95\% CI $(-5.94-5.14)$ for the difference in ORR $(-0.40 \%)$ between the two treatments was within the prespecified equivalence margin of $\pm 12 \%$. Median follow-up for the primary analysis was 11.6 months. PFS and OS were included descriptively as secondary efficacy objectives; however, the power to show equivalence based on PFS was calculated to be less than $1 \%$, for the number of patients enrolled and a median estimated PFS of 36 months. At data cut-off, patients in either group did not reach the estimated median PFS or OS, highlighting the unsuitability of time-dependent survival-based end points for biosimilarity trials.

The goal of a comparative clinical trial is to demonstrate the potential biosimilar is equivalent to the originator; therefore, studies are conducted using an equivalence design (i.e., where the difference in efficacy or safety between the potential biosimilar and originator product is less than a prespecified margin of clinical equivalence) [73-75]. Bearing in mind that response rate (i.e., lack of demonstrable treatment effect) is preferable as a primary end point in biosimilar trials [55], not all patient populations in which the originator is indicated as a first-line therapy (particularly in oncology indications) may be considered suitably sensitive to detect differences, should they exist.

Taking the above factors into account, patients with previously untreated, advanced NSCLC are considered a sensitive population, suitable for the evaluation of potential biosimilars to bevacizumab when combined in a treatment regimen with paclitaxel and carboplatin [75]. Comparative clinical trials in patients with NSCLC have been registered for an approved biosimilar; a number of potential biosimilars to bevacizumab are in the advanced stages of development (Table 2). In all of the studies listed, the primary end point is ORR. For instance, the potential biosimilar bevacizumab PF-06439535 was compared with bevacizumab-EU in combination with paclitaxel and carboplatin, a treatment regimen for which safety and efficacy profile in patients with advanced nonsquamous NSCLC is well understood [77]. Based on the treatment effect, using ORR as end point in clinical studies of originator bevacizumab [78], the NSCLC patient population was considered suitably sensitive to detect differences between the products should they exist [79]. In this double-blind, randomized, parallel-group clinical trial (NCT02364999), equivalence in the primary end point was demonstrated by week 19 [80], based on the $90 \%$ 
CI of the relative risk of ORR of PF-06439535 versus bevacizumab-EU, which was within a prespecified margin of $76-132 \%[77]$.

\section{Approved biosimilars}

To date, the EMA has granted marketing authorization for more than 20 biosimilars within the product classes of insulin, human growth hormone, granulocyte colony-stimulating factor, erythropoiesis-stimulating agents, folliclestimulating hormone and TNF inhibitors [83,84]. In the USA, six biosimilars are currently licensed: adalimumab, etanercept, filgrastim, infliximab and bevacizumab [85]. The introduction of biosimilars is anticipated to bring cost savings in healthcare budgets and increased patient access. In a study to identify key drivers for the uptake of biosimilars in the top $10 \mathrm{EU}$ member state pharmaceutical markets, average biosimilar price discount was approximately 15\%, with the discount (range: 0-32\%) dependent on the product and the country [86]. A separate analysis of the impact of competition arising from the introduction of biosimilars in Europe (23 countries) found that this led to increased consumption, based on change in treatment days for biosimilars and originator products (2016, the year before biosimilar entrance), as a proxy for patient access [87]. This increase in consumption ranged from $16 \%$ for gonadotropins (follicle-stimulating hormones and luteinizing hormone) to $122 \%$ for granulocytecolony stimulating factors. Biosimilar experience in the USA is more recent than in Europe. Considerable reductions of direct spending on biologic drugs are anticipated due to the introduction of biosimilars, with the actual cost savings hinging on the level of competition and issues around reimbursement [88].

Biosimilars to epoetin and filgrastim are approved for all indications of the originators, and more than 9 years of experience of epoetin biosimilars in Europe have illustrated that the efficacy and safety profiles of biosimilar epoetin are similar to those of the originator $[89,90]$. The totality of evidence, demonstrating biosimilarity of the epoetin biosimilars with originator, and the mechanism of action for epoetin judged as consistent across all approved indications support extrapolation [64]. Similarly, filgrastim biosimilars have received approval for the indications of the originator via extrapolation based on the evidence supporting similarity between the biosimilars and the originator in terms of analytical assessments, PK/PD studies, efficacy and safety in patients, and a single mechanism of action [64].

\section{Conclusion}

Bevacizumab inhibits angiogenesis and is the standard of care for a multitude of malignancies; however, patient access to bevacizumab may be limited due to a variety of factors. The availability of biosimilar versions of bevacizumab could increase access, thereby meeting the needs of patients with cancer. The development program for a potential biosimilar is more tailored, but the assessment is just as rigorous compared with those required for a new biologic medicine. The resultant savings in development costs for a biosimilar and the impact on pricing due to greater competition offer the potential of more affordable treatment options. This is achieved without compromising quality, as biosimilarity is established based on rigorous and comprehensive comparability studies, which encompass structural, functional and clinical data.

The process of extrapolation is a key element of the biosimilar approval process. By following a carefully designed and tailored development program, manufacturers can increase the availability of biologic therapies for patients. For consideration of extrapolation by regulatory authorities, biosimilarity must be shown based on a rigorous comparability assessment involving efficacy, safety and immunogenicity in a relevant indication.

Additional considerations include the mechanism of action in each indication and the target receptors involved. Since the mechanism of action of bevacizumab is well understood - namely inhibition of VEGFR-mediated endothelial cell proliferation and angiogenesis - provided the analytical assessment of a potential biosimilar shows similarity with bevacizumab, it is not necessary to conduct trials in patients with each tumor type approved for the innovator product. Ultimately, regulatory authorities will assess the available evidence for each proposed bevacizumab biosimilar on a case-by-case basis and determine whether to authorize them for additional indications via extrapolation. Significant clinical experience to date with approved and licensed biosimilars has shown, as anticipated, that biosimilars behave similarly to the originator products, including in indications that were approved through the process of extrapolation [91], and has expanded patient access to needed biologic therapies [87].

The FDA has approved the first bevacizumab biosimilar [22]. Many potential biosimilars are currently in development and being tested in the clinical trial setting. The utility of response rate as an end point to demonstrate the clinical effectiveness of drug treatments in oncology is recognized and accepted by regulatory bodies. Adoption of the response rate in establishing comparability in a head-to-head trial in a relevant indication of a potential 
biosimilar and originator, as part of the totality of evidence to demonstrate biosimilarity, provides the scientific justification for extrapolating data of bevacizumab biosimilars to the treatment of patients with other tumor types where the originator product is approved.

\section{Future perspective}

A number of biosimilars of bevacizumab are expected to be available in the near future, increasing the treatment options available for clinicians to consider for their patients. Bevacizumab biosimilars approved by regulatory bodies with robust and well-established pathways, for example, the FDA and EMA, will likely be authorized for most or all of the eligible indications of originator bevacizumab (i.e., not covered by regulatory exclusivity), based on extrapolation of data from a single comparative clinical trial in patients with NSCLC. Any current uncertainty by clinicians as to the basis for extrapolation of bevacizumab biosimilar data from patients with NSCLC to colorectal, and other cancers, as well as vindication of this regulatory mechanism, will be addressed with the accumulation of real-world experience of bevacizumab biosimilars in these patient populations.

Financial \& competing interests disclosure

DA Reardon has participated in Speaker's Bureau for Genentech/Roche and Merck; participated in Advisory boards for Abbvie, Agenus, Amgen, BMS, Cavion, Celldex, EMD Serono, Genentech/Roche, Inovio, Juno Pharmaceuticals, Merck, Midatech, Momenta Pharmaceuticals, Novartis, Novocure, Oncorus, Oxigene, Regeneron and Stemline Therapeutics; and received research funding from Acerta Pharma, Agenus, Celldex Therapeutics, EMD Serono, Incyte, Inovio, Midatech and Tragara. J Subramanian has participated in Speaker's Bureau for AstraZeneca, Boehringer Ingelheim and Lilly; served as a consultant for AstraZeneca, Alexion, Pfizer, Boehringer Ingelheim and Merck; and received research funding from Biocept and Paradigm. AH Bair and I Jacobs are employees of and hold stock in Pfizer, Inc. The authors have no other relevant affiliations or financial involvement with any organization or entity with a financial interest in or financial conflict with the subject matter or materials discussed in the manuscript apart from those disclosed.

Medical writing support was provided by M Saba and I McDonald of Engage Scientific Solutions and was funded by Pfizer, Inc.

\section{Open access}

This work is licensed under the Attribution-NonCommercial-NoDerivatives 4.0 Unported License. To view a copy of this license, visit http://creativecommons.org/licenses/by-nc-nd/4.0/ 
Executive summary

- Biosimilars of bevacizumab have the potential to increase access and to improve clinical outcomes for patients across a number of cancers.

- Regulatory agencies permit extrapolation of data for a biosimilar, allowing its approval for use for an eligible indication (i.e., not covered by regulatory exclusivity) in which the originator is authorized, without the need for a comparative clinical trial.

VEGF $\&$ bevacizumab mechanism of action

- VEGF plays a central role in tumor angiogenesis and has been implicated in both tumor vascularization and metastases.

- Bevacizumab binds to VEGF, resulting in blockade of VEGF receptor and inhibition of angiogenesis.

Demonstrating biosimilarity

- Biosimilarity is based on establishing that the quality, safety and efficacy of the biosimilar and the originator are comparable, to the extent that clinically meaningful differences should not be expected.

- Approval of biosimilars is based on the assessment of the totality of evidence, encompassing comparative analytical, nonclinical, pharmacokinetic (PK)/ pharmacodynamic (PD) and clinical data.

Principles of extrapolation

- Extrapolation is a well-established and accepted principle that is based on applying the conclusions from a study conducted in one population to make inferences for another population.

- The mechanism of action and PK of the originator should be consistent across indications, forming the basis for justification of extrapolation.

- The disease of the patient population chosen for the comparability study of the originator and potential biosimilar should be sufficiently sensitive to identify a difference, should one exist.

Bevacizumab biosimilars: considerations for development $\&$ approval

- Based on nonclinical functional assessments, there is no evidence to support a unique mechanism of action for bevacizumab across tumor types.

- The PK properties of bevacizumab are acknowledged as being consistent across the approved indications.

- Patients with non-small-cell lung cancer are considered a suitably sensitive population to detect differences between bevacizumab and a potential biosimilar, should they exist.

- Use of a response rather than survival-based end point is preferred, since the latter can be influenced by factors other than treatment-related differences, and bioequivalence can be established with a relatively shorter follow-up period.

Approved biosimilars

- The EMA and US FDA have granted marketing authorization for more than 25 biosimilars across a number of product classes.

- Some have been approved in indications for which the originator is authorized without direct clinical comparison, through extrapolation.

- Introduction of biosimilars is anticipated to bring cost savings in healthcare budgets and increased patient access.

- The first biosimilar of bevacizumab has been approved by the FDA; a number of potential biosimilars of bevacizumab are in the advanced stages of development.

Conclusion

- The process of extrapolation is a key element of the biosimilar approval process, with manufacturers required to implement development programs that are carefully designed to provide the relevant data to support it.

- Provided the totality of evidence for bevacizumab biosimilars comprises appropriate comparative analytical, nonclinical, PK/PD data as well as a clinical study, most suitably conducted in patients with non-small-cell lung cancer, extrapolation to other eligible indications, such as colorectal, and other cancers, can be scientifically justified.

\section{References}

Papers of special note have been highlighted as: • of interest; $\bullet \bullet$ of considerable interest

1. Genentech Inc. Avastin (bevacizumab) US prescribing information (2016). www.gene.com/download/pdf/avastin_prescribing.pdf

2. Roche Registration Limited, EMA. Avastin summary of product characteristics (2015). www.ema.europa.eu/ema/index.jsp?curl=pages/m edicines/human/medicines/000582/human_med_000663.jsp\&mid=WC0b01ac058001d124

3. Source: F Hoffmann-La Roche Ltd. Roche receives EU approval of avastin in combination with Tarceva for patients with a specific type of advanced lung cancer. Press release: www.roche.com/dam/jcr:82895714-0fc4-4834-b087-d01d1e769258/en/med-cor-2016-06-08-e.pdf

4. Hurwitz H, Fehrenbacher L, Novotny W et al. Bevacizumab plus irinotecan, fluorouracil, and leucovorin for metastatic colorectal cancer. N. Engl. J. Med. 350(23), 2335-2342 (2004). 
5. Sandler A, Gray R, Perry MC et al. Paclitaxel-carboplatin alone or with bevacizumab for non-small-cell lung cancer. $N$. Engl. J. Med. 355(24), 2542-2550 (2006).

6. Escudier B, Pluzanska A, Koralewski $P$ et al. Bevacizumab plus interferon alfa-2a for treatment of metastatic renal cell carcinoma: a randomised, double-blind Phase III trial. Lancet 370(9605), 2103-2111 (2007).

7. Miller K, Wang M, Gralow J et al. Paclitaxel plus bevacizumab versus paclitaxel alone for metastatic breast cancer. N. Engl. J. Med. 357(26), 2666-2676 (2007).

8. Friedman HS, Prados MD, Wen PY et al. Bevacizumab alone and in combination with irinotecan in recurrent glioblastoma. J. Clin Oncol. 27(28), 4733-4740 (2009).

9. Tewari KS, Sill MW, Long HJ 3rd et al. Improved survival with bevacizumab in advanced cervical cancer. N. Engl. J. Med. 370(8), 734-743 (2014).

10. Pujade-Lauraine E, Hilpert F, Weber B et al. Bevacizumab combined with chemotherapy for platinum-resistant recurrent ovarian cancer: the AURELIA open-label randomized Phase III trial. J. Clin. Oncol. 32(13), 1302-1308 (2014).

11. Burger RA, Brady MF, Bookman MA et al. Incorporation of bevacizumab in the primary treatment of ovarian cancer. N. Engl. J. Med. 365(26), 2473-2483 (2011).

12. Aghajanian C, Blank SV, Goff BA et al. OCEANS: a randomized, double-blind, placebo-controlled Phase III trial of chemotherapy with or without bevacizumab in patients with platinum-sensitive recurrent epithelial ovarian, primary peritoneal, or fallopian tube cancer. $J$. Clin. Oncol. 30(17), 2039-2045 (2012).

13. Cherny N, Sullivan R, Torode J, Saar M, Eniu A. ESMO European Consortium study on the availability, out-of-pocket costs and accessibility of antineoplastic medicines in Europe. Ann. Oncol. 27(8), 1423-1443 (2016).

14. Poonawalla IB, Parikh RC, Du XL, VonVille HM, Lairson DR. Cost-effectiveness of chemotherapeutic agents and targeted biologics in ovarian cancer: a systematic review. Pharmacoeconomics 33(11), 1155-1185 (2015).

15. Monk B, Lammers P, Cartwright T, Jacobs I. Barriers to the access of bevacizumab in patients with solid tumors and the potential impact of biosimilars: a physician survey. Pharmaceuticals (Basel) 10(1), doi:10.3390/ph10010019 (2017).

16. Schellekens H. Biosimilar therapeutics-what do we need to consider? NDT Plus 2(Suppl. 1), I27-I36 (2009).

17. Walsh G, Jefferis R. Post-translational modifications in the context of therapeutic proteins. Nat. Biotechnol. 24(10), 1241-1252 (2006).

18. Schiestl M, Stangler T, Torella C, Cepeljnik T, Toll H, Grau R. Acceptable changes in quality attributes of glycosylated biopharmaceuticals. Nat. Biotechnol. 29(4), 310-312 (2011).

19. WHO, Expert Committee on Biological Standardization. Guidelines on evaluation of similar biotherapeutic products (SBPs) (2009). www.who.int/biologicals/areas/biological_therapeutics/BIOTHERAPEUTICS_FOR_WEB_22APRIL2010.pdf

20. EMA, Committee for Medicinal Products for Human Use. Guideline on similar biological medicinal products containing biotechnology-derived proteins as active substance: non-clinical and clinical issues (2015). www.ema.europa.eu/docs/en_GB/document_library/Scientific_guideline/2015/01/WC500180219.pdf

21. US FDA, Center for Drug Evaluation and Research. Scientific considerations in demonstrating biosimilarity to a reference product. Guidance for Industry (2015). www.fda.gov/downloads/Drugs/GuidanceComplianceRegulatoryInformation/Guidances/UCM291128.pdf

22. US FDA. FDA approves first biosimilar for the treatment of cancer [media release] (2017). www.fda.gov/NewsEvents/Newsroom/PressAnnouncements/ucm576112.htm

23. Generics and Biosimilars Initiative (GaBI). Biosimilars of bevacizumab (2017). http://gabionline.net/Biosimilars/General/Biosimilars-of-bevacizumab

24. Weise M, Kurki P, Wolff-Holz E, Bielsky MC, Schneider CK. Biosimilars: the science of extrapolation. Blood 124(22), 3191-3196 (2014).

-• Review of the scientific and regulatory decision-making relating to the extrapolation of indications for biosimilars, supported by examples from approved products.

25. Ferrara N. Vascular endothelial growth factor as a target for anticancer therapy. Oncologist 9(Suppl. 1), 2-10 (2004).

26. Gavalas NG, Liontos M, Trachana SP et al. Angiogenesis-related pathways in the pathogenesis of ovarian cancer. Int. J. Mol. Sci. 14(8), 15885-15909 (2013)

27. Shibuya M. Vascular endothelial growth factor (VEGF) and its receptor (VEGFR) signaling in angiogenesis: a crucial target for anti- and pro-angiogenic therapies. Genes Cancer 2(12), 1097-1105 (2011).

28. Kroep JR, Nortier JW. The role of bevacizumab in advanced epithelial ovarian cancer. Curr. Pharm. Des. 18(25), 3775-3783 (2012).

29. Seto T, Higashiyama M, Funai $\mathrm{H}$ et al. Prognostic value of expression of vascular endothelial growth factor and its flt-1 and KDR receptors in stage I non-small-cell lung cancer. Lung Cancer 53(1), 91-96 (2006).

30. Des Guetz G, Uzzan B, Nicolas P et al. Microvessel density and VEGF expression are prognostic factors in colorectal cancer. Meta-analysis of the literature. Br. J. Cancer 91(12), 1823-1832 (2006). 
31. Flynn JR, Wang L, Gillespie DL et al. Hypoxia-regulated protein expression, patient characteristics, and preoperative imaging as predictors of survival in adults with glioblastoma multiforme. Cancer 113(5), 1032-1042 (2008).

32. Paley PJ, Staskus KA, Gebhard K et al. Vascular endothelial growth factor expression in early stage ovarian carcinoma. Cancer 80(1), 98-106 (1997).

33. Fontanini G, Vignati S, Boldrini L et al. Vascular endothelial growth factor is associated with neovascularization and influences progression of non-small cell lung carcinoma. Clin. Cancer Res. 3(6), 861-865 (1997).

34. Kumar H, Heer K, Lee PW et al. Preoperative serum vascular endothelial growth factor can predict stage in colorectal cancer. Clin. Cancer Res. 4(5), 1279-1285 (1998).

35. Cooper BC, Ritchie JM, Broghammer CL et al. Preoperative serum vascular endothelial growth factor levels: significance in ovarian cancer. Clin. Cancer Res. 8(10), 3193-3197 (2002).

36. Hefler LA, Zeillinger R, Grimm C et al. Preoperative serum vascular endothelial growth factor as a prognostic parameter in ovarian cancer. Gynecol. Oncol. 103(2), 512-517 (2006).

37. Kim KJ, Li B, Houck K, Winer J, Ferrara N. The vascular endothelial growth factor proteins: identification of biologically relevant regions by neutralizing monoclonal antibodies. Growth Factors 7(1), 53-64 (1992).

38. Kim KJ, Li B, Winer J et al. Inhibition of vascular endothelial growth factor-induced angiogenesis suppresses tumour growth in vivo. Nature 362(6423), 841-844 (1993).

39. Della Pepa C, Banerjee S. Bevacizumab in combination with chemotherapy in platinum-sensitive ovarian cancer. Onco. Targets Ther. 7 , 1025-1032 (2014).

40. Ellis LM. Mechanisms of action of bevacizumab as a component of therapy for metastatic colorectal cancer. Semin. Oncol. $33(5$ Suppl. 10), S1-S7 (2006).

41. Hasan MR, Ho SH, Owen DA, Tai IT. Inhibition of VEGF induces cellular senescence in colorectal cancer cells. Int. J. Cancer 129(9), 2115-2123 (2011).

42. Wang Y, Fei D, Vanderlaan M, Song A. Biological activity of bevacizumab, a humanized anti-VEGF antibody in vitro. Angiogenesis 7(4), 335-345 (2004).

43. Jain RK, Duda DG, Willett CG et al. Biomarkers of response and resistance to antiangiogenic therapy. Nat. Rev. Clin. Oncol. 6(6), 327-338 (2009).

44. Lai Z, La Noce A. Key design considerations on comparative clinical efficacy studies for biosimilars: adalimumab as an example. $R M D$ Open 2(1), e000154 (2016).

- Review of the aspects to be considered in the design of comparative Phase III clinical trials to demonstrate biosimilarity, including therapeutic indication, patient population, background therapy, blinding, stratification, transition design, choice of equivalence versus noninferiority design, equivalence margin and alternative statistical considerations.

45. International Pharmaceutical Regulators Forum Biosimilars Working Group. Reflection paper on extrapolation of indications in authorization of biosimilar products version 1.3 (2016). www.i-p-r-f.org/files/1614/7315/4963/160725_IPRF_BWG_Reflection_paper_final_draftver_1.3_IPRF_MC_Circulation.pdf

46. Socinski MA, Curigliano G, Jacobs I, Gumbiner B, MacDonald J, Thomas D. Clinical considerations for the development of biosimilars in oncology. MAbs 7(2), 286-293 (2015).

- Article on considerations about the development of biosimilars in cancer treatment, covering unique regulatory requirements, labeling considerations and potential limitations to the uptake of biosimilars.

47. Rugo HS, Linton KM, Cervi P, Rosenberg JA, Jacobs I. A clinician's guide to biosimilars in oncology. Cancer Treat. Rev. 46, 73-79 (2016).

48. Ogura M, Coiffier B, Kwon HC, Yoon SW. Scientific rationale for extrapolation of biosimilar data across cancer indications: case study of CT-P10. Future Oncol. 13(15 Suppl.), 45-53 (2017).

49. Berkowitz SA, Engen JR, Mazzeo JR, Jones GB. Analytical tools for characterizing biopharmaceuticals and the implications for biosimilars. Nat. Rev. Drug Discov. 11(7), 527-540 (2012).

-• Overview of the pivotal role of analytical technologies in comparing biosimilars with the corresponding reference product and their importance in development pathway for biosimilars. The state of the art analytical technologies that are used to assess the key protein characteristics of post-translational modifications, 3D structures and protein aggregation is highlighted.

50. Declerck PJ. Biosimilar monoclonal antibodies: a science-based regulatory challenge. Expert Opin. Biol. Ther. 13(2), $153-156$ (2013).

51. Shang TQ, Saati A, Toler KN et al. Development and application of a robust $\mathrm{N}$-glycan profiling method for heightened characterization of monoclonal antibodies and related glycoproteins. J. Pharm. Sci. 103(7), 1967-1978 (2014).

52. Greer F. Biosimilar drug development and the importance of analytical characterization. GaBi Online (2015). www.gabionline.net/Sponsored-Articles/Biosimilar-drug-development-and-the-importance-of-analytical-characterization

53. Hubert P, Amigorena S. Antibody-dependent cell cytotoxicity in monoclonal antibody-mediated tumor immunotherapy. Oncoimmunology 1(1), 103-105 (2012). 
54. WHO, Expert Committee on Biological Standardization. Guidelines on evaluation of monoclonal antibodies as similar biotherapeutic products (SBPs) (2016).

www.who.int/biologicals/expert_committee/mAb_SBP_GL-ECBS_review_adoption-2016.10.26--11.7post_ECBS-Clean_Version.pdf

55. EMA. Guideline on similar biological medicinal products containing monoclonal antibodies - non-clinical and clinical issues (2012). www.ema.europa.eu/docs/en_GB/document_library/Scientific_guideline/2012/06/WC500128686.pdf

56. Chapman K, Adjei A, Baldrick P et al. Waiving in vivo studies for monoclonal antibody biosimilar development: national and global challenges. MAbs 8(3), 427-435 (2016).

57. van Aerts LA, De Smet K, Reichmann G, van der Laan JW, Schneider CK. Biosimilars entering the clinic without animal studies. A paradigm shift in the European Union. MAbs 6(5), 1155-1162 (2014).

58. EMA. Herceptin $150 \mathrm{mg}$ powder for concentrate for solution for infusion (2017). www.ema.europa.eu/docs/en_GB/document_library/EPAR_-_Product_Information/human/000278/WC500074922.pdf

59. EMA. Herceptin $600 \mathrm{mg}$ solution for injection in vial (2016). www.medicines.org.uk/emc/medicine/28179/SPC/Herceptin+600+mg+5+ml+Solution+for+Injection/

60. Wynne C, Harvey V, Schwabe C, Waaka D, McIntyre C, Bittner B. Comparison of subcutaneous and intravenous administration of trastuzumab: a Phase I/Ib trial in healthy male volunteers and patients with HER2-positive breast cancer. J. Clin. Pharmacol. 53(2), 192-201 (2013).

61. Ismael G, Hegg R, Muehlbauer S et al. Subcutaneous versus intravenous administration of (neo)adjuvant trastuzumab in patients with HER2-positive, clinical stage I-III breast cancer (HannaH study): a Phase 3, open-label, multicentre, randomised trial. Lancet Oncol. 13(9), 869-878 (2012).

62. Jackisch C, Kim SB, Semiglazov V et al. Subcutaneous versus intravenous formulation of trastuzumab for HER2-positive early breast cancer: updated results from the Phase III HannaH study. Ann. Oncol. 26(2), 320-325 (2015).

63. EMA, Committee for Medicinal Products for Human Use. Herceptin, CHMP assessment report (2013). www.ema.europa.eu/docs/e n_GB/document_library/EPAR_-_Assessment_Report_-_Variation/human/000278/WC500153233.pdf

64. Curigliano G, O'Connor DP, Rosenberg JA, Jacobs I. Biosimilars: extrapolation for oncology. Crit. Rev. Oncol. Hematol. 104, 131-137 (2016).

65. US Food and Drug Administration. FDA briefing document. Oncologic Drugs Advisory Committee. BLA 761028. ABP 215, a proposed biosimilar to Avastin (bevacizumab) Amgen Inc (2017). www.fda.gov/downloads/AdvisoryCommittees/CommitteesMeeting Materials/Drugs/OncologicDrugsAdvisoryCommittee/UCM566365.pdf

66. Lu JF, Bruno R, Eppler S, Novotny W, Lum B, Gaudreault J. Clinical pharmacokinetics of bevacizumab in patients with solid tumors. Cancer Chemother. Pharmacol. 62(5), 779-786 (2008).

67. Born TL, Huynh Q, Mathur A et al. Functional similarity assessment results comparing bevacizumab to biosimilar candidate ABP215. Ann. Oncol. 25(Suppl. 4), iv163 (2014).

68. Markus R, Chow V, Pan Z, Hanes V. A Phase I, randomized, single-dose study evaluating the pharmacokinetic equivalence of biosimilar ABP 215 and bevacizumab in healthy adult men. Cancer Chemother. Pharmacol. 80(4), 755-763 (2017).

-• Phase I comparative clinical trial in healthy subjects, showing the pharmacokinetic similarity of ABP 215, a bevacizumab biosimilar, and originator bevacizumab.

69. Thatcher N, Thomas M, Paz-Ares L et al. Randomized, double-blind, Phase 3 study evaluating efficacy and safety of ABP 215 compared with bevacizumab in patients with non-squamous NSCLC. J. Clin. Oncol. 34(Suppl.), Abstract 9095 (2016).

70. Peraza MA, Rule KE, Shiue MHI et al. Nonclinical assessments of the potential biosimilar PF-06439535 and bevacizumab. Regul. Toxicol. Pharmacol. 95, 236-243 (2018).

71. Knight B, Rassam D, Liao S, Ewesuedo R. A Phase I pharmacokinetics study comparing PF-06439535 (a potential biosimilar) with bevacizumab in healthy male volunteers. Cancer Chemother. Pharmacol. 77(4), 839-846 (2016).

-• Phase I comparative clinical trial in healthy subjects, showing the pharmacokinetic similarity of PF-06439535, a potential bevacizumab biosimilar, and originator bevacizumab.

72. Weise M, Bielsky MC, De Smet K et al. Biosimilars: what clinicians should know. Blood 120(26), 5111-5117 (2012).

73. Alten R, Cronstein BN. Clinical trial development for biosimilars. Semin. Arthritis Rheum. 44(6 Suppl.), S2-S8 (2015).

74. Dranitsaris G, Dorward K, Hatzimichael E, Amir E. Clinical trial design in biosimilar drug development. Invest. New Drugs 31(2), 479-487 (2013).

75. Isakov L, Jin B, Jacobs IA. Statistical primer on biosimilar clinical development. Am. J. Ther. 23(6), e1903-e1910 (2016).

76. Jurczak W, Moreira I, Kanakasetty GB et al. Rituximab biosimilar and reference rituximab in patients with previously untreated advanced follicular lymphoma (ASSIST-FL): primary results from a confirmatory Phase 3, double-blind, randomised, controlled study. Lancet Haematol. 4(8), e350-e361 (2017).

77. Desai B, Rassam D, Ezeh P et al. Phase III trial of PF 06439535 or bevacizumab-EU plus paclitaxel/carboplatin in NSCLC. J. Thorac. Oncol. 10(29), S665 (2015). 
78. Botrel TE, Clark O, Clark L, Paladini L, Faleiros E, Pegoretti B. Efficacy of bevacizumab (Bev) plus chemotherapy (CT) compared to $\mathrm{CT}$ alone in previously untreated locally advanced or metastatic non-small cell lung cancer (NSCLC): systematic review and meta-analysis. Lung Cancer 74(1), 89-97 (2011).

79. Rosen LS, Jacobs IA, Burkes RL. Bevacizumab in colorectal cancer: current role in treatment and the potential of biosimilars. Target Oncol. 12(5), 599-610 (2017).

80. Source: Pfizer Inc. Pfizer announces positive top-line results from the comparative REFLECTIONS B7391003 study for PF-06439535, a potential biosimilar to Avastin ${ }^{\circledR}$ (bevacizumab). Press release: www.pfizer.com/news/press-release/press-release-detail/pfizer_announces_positive_top_line_results_from_the_comparative_reflections_b 7391003_study_for_pf_06439535_a_potential_biosimilar_to_avastin_1_bevacizumab

81. Thatcher N, Thomas M, Ostoros G, Pan Z, Goldschmidt JH, Hanes V. Secondary efficacy results from a Phase 3 study comparing efficacy and safety of biosimilar candidate ABP 215 with bevacizumab in patients with non-squamous non-small cell lung cancer (NSCLC). Ann. Oncol. 27, VI411-VI415 (2016).

82. Filon O, Orlov S, Burdaeva O et al. Efficay and safety of BCD-021, bevacizumab biosimilar candidate, compared to Avastin: results of international multicenter randomized double blind Phase III study in patients with advanced non-squamous NSCLC. J. Clin. Oncol. 33(Suppl.), Abstract 8057 (2015).

83. European Medicines Agency. European public assessment reports. Biosimilars (2016).

www.ema.europa.eu/ema/index.jsp?curl=pages\%2Fmedicines\%2Flanding\%2Fepar_search.jsp\&mid=WC0b01ac058001d124\&searchT $\mathrm{ab}=$ searchByAuthType\&alreadyLoaded=true\&isNewQuery=true\&status=Authorised\&status=Withdrawn\&keyword=Enter+keyword s\&searchType=name\&taxonomyPath=\&treeNumber=\&searchGenericType=biosimilars

84. Generics and Biosimilars Initiative (GaBi). Biosimilars approved in Europe (2017). www.gabionline.net/Biosimilars/General/Biosimilars-approved-in-Europe

85. Center for Drug Evaluation and Research (CDER). CDER list of licensed biological products (2017). www.fda.gov/downloads/Drugs/DevelopmentApprovalProcess/HowDrugsareDevelopedandApproved/ApprovalApplications/Therapeuti cBiologicApplications/Biosimilars/UCM560162.pdf

86. Remuzat C, Dorey J, Cristeau O, Ionescu D, Radiere G, Toumi M. Key drivers for market penetration of biosimilars in Europe. J. Mark. Access Health Policy 5(1), 1272308 (2017).

87. QuntilesIMS. The impact of biosimilar completion (2017). www.medicinesforeurope.com/wp-content/uploads/2017/05/IMS-Biosimilar-2017_V9.pdf

88. Mulcahy AW, Predmore Z, Mattke S. The cost savings potential of biosimilar drugs in the United States (2014). www.rand.org/content/dam/rand/pubs/perspectives/PE100/PE127/RAND_PE127.pdf

89. Dingermann T, Scotte F. Biosimilar epoetin zeta: extrapolation of indications and real world utilization experience. Expert Opin. Biol. Ther. 16(7), 967-974 (2016).

90. Fishbane S, Shah HH. The emerging role of biosimilar epoetins in nephrology in the United States. Am. J. Kidney Dis. 65(4), 537-542 (2015).

91. Jorgensen KK, Olsen IC, Goll GL et al. Switching from originator infliximab to biosimilar CT-P13 compared with maintained treatment with originator infliximab (NOR-SWITCH): a 52-week, randomised, double-blind, non-inferiority trial. Lancet 389(10086), 2304-2316 (2017). 